\title{
EFFECTS OF MATERNAL PROTEIC UNDERNUTRITION ON THE NEURONS OF THE MYENTERIC PLEXUS OF THE DUODENUM OF RATS
}

\author{
MARIA RAQUEL MARÇAL NATALI*, MARCILLIO H. MIRANDA-NETO* *
}

\begin{abstract}
The purpose of this study was to verify the effects of proteic undernutrition on the neurons of the myenteric plexus from the duodenum of Wistar rats. Twenty-four animals at the age of 60 days were divided in four groups, which were named according to the period their mothers received hypoproteic ration (8\%). Some segments of duodenum were subjected to histological treatment and stained with hematoxilin-eosin and some were used for whole mount preparations stained with Giemsa. We observed small, medium-sized and large neurons grouped in ganglia of various shapes. It was concluded that the maternal proteic undernutrition does not affect the organization of the myenteric plexus and that animals submitted to undernutrition during gestation and lactation, when normally fed, show neurons with strongly basophilic cytoplasm and larger cellular bodies than those from control animals.
\end{abstract}

KEY WORDS: myenteric neurons, proteic undernutrition, myenteric plexus.

Efeitos da desnutriçăo proteica materna sobre os neurônios do plexo mientérico do duodeno de ratos

RESUMO - O propósito deste estudo foi investigar os efeitos da desnutrição proteica sobre os neurônios do plexo mientérico do duodeno de ratos Wistar. Vinte e quatro animais com 60 dias de idade foram divididos em 4 grupos e denominados de acordo com o periodo em que suas mães receberam raç㐅㐅̆o hipoproteica (8\%). Alguns segmentos de duodeno foram submetidos a tratamento histológico e corados com hematoxilina-eosina $\mathrm{e}$ alguns foram utilizados na elaboraçăo dos preparados de membrana corados com Giemsa. Observamos neurônios pequenos, médios e grandes formando gânglios de formatos diversos. Concluiu-se que a desnutriçăo proteica materna não afeta a organização do plexo mientérico e que animais desnutridos na gestação e lactação quando voltam a receber dieta com teor proteico normal apresentam neurônios com citoplasma fortemente basofilico e geralmente maiores que o de animais normo-alimentados.

PALAVRAS-CHAVE: neurônios mientéricos, desnutrição proteica, plexo mientérico.

When we look up the literature concerning proteic undernutrition on different parts of the organism, we find effects on the central nervous system ${ }^{3,15,26,27}$, but few are the works concerned with the effects of undernutrition on the peripheral nervous system, and even rarer when the neurons of the myenteric plexus are involved, which are responsible for the intestinal motility. The myenteric plexus has morphological and quantitative features that vary on the different parts of the intestinal gut in humans and animals $\mathrm{s}^{8,10.11,13.16,23}$. A previous study of the small intestine of rats whose mothers were submitted to proteic deprivation during gestation ${ }^{20}$ did not find alterations on the activity of the

Departament of Morphophysiological Science of the State University of Maringá, Paraná: * Assistant Professor; ${ }^{* *}$ Adjunct Professor. This paper is part of the M.A. Dissertation of M.R.M. Natali. Aceite: 4-janeiro1996.

Dr. Marcilio Hubner de Miranda Neto - Universidade Estadual de Maringá - Avenida Colombo 5790 Bloco H-79 Sala 07 - 87020-900 Maringá PR - Brasil. 
myenteric plexus. In another study ${ }^{4}$ the authors verified that the neurons of the superior celiac mesenteric ganglion seem smaller and the ganglia form compact structures in rats whose mothers suffered undernutrition during gestation. In relation to the number of myenteric neurons, it was found a $27 \%$ reduction on the jejune of 140 day-old rats born of mothers underfed during the last two weeks of gestation ${ }^{19}$.

We therefore noted that gaps exist on the literature about different post-undernutrition periods; this fact elicited us to study the neurons of the myenteric plexus of rats whose mothers suffered proteic undernutrition on gestation, lactation, or both, and were recovered afterwards with a normal proteic diet for 39 and 60 days, according to the considered group.

\section{MATERIAL AND METHOD}

This study was carried out on the duodenum of twenty-four Wistar rats with 60 days of age. To obtain the various nutritional groups NUVILAB ration (recommended by the National Research Council and National Institute of Health, USA) with a $22 \%$ proteic level was used. The proteic level was lowered to $8 \%$ by the addition of starch. Both rations were given in pellets and the proteic levels were tested using the nitrogen dosage by the Semimicro Kjedahl method ${ }^{21}$ The hypoproteic diet was supplemented with a B vitamin complex and a mixture of mineral salts ${ }^{15,17}$.

According to the period the mothers received hypoproteic diet the groups were named $\mathrm{NN}$ (control): received normal proteic ( $22 \%$ ) ration. DN (experimental): received hypoproteic ( $8 \%$ ) ration during gestation and normal ration during lactation. ND (experimental): received normal diet during gestation and a hypoproteic one during lactation. DD (experimental): received hypoproteic diet both on gestation and lactation.

After breast-feeding ( 21 days), all the young were fed normally until the $60^{\text {th }}$ day of age when they were weighted, sacrificed and their intestines measured.

For the morphological and quantitative analysis of the myenteric neurons, samples of $42 \mathrm{~mm}$ from the initial segment of the duodenum were used for whole mount preparations'. With a Olympus CBB microscope (coupled with a micrometer disc) the major axis of the cellular body was measured and the shape of the cell, nucleus position and number of nucleoli were observed. A Nikon Labophot microscope (ocular CFW 10x and lens $40 x$ ) was used for the neuronal quantification.

In each slide the number of cells per ganglion and the number of ganglia in each segment were counted. These data, along with the sample area, were used to calculate the neuronal and ganglionar density.

The whole mount preparations were photographed with a photomicroscope Wild M20 and photographic equipment Wild MPS-55.

Statistic treatment: data from the animal's weight, small intestine length and major axis of the cellular body were analysed for significance through student's $T$ test. For the analysis of neuronal and ganglionar density on the duodenum and of the significance of data concerning incidence of neuronal size (small, medium-size and large) the $\mathrm{X}^{2}$ test was used. The significance level adopted in both cases was $5 \%$.

\section{RESULTS}

1. Ganglionar location and shape: the nervous ganglia of the myenteric plexus were located between the circular and longitudinal layers of the muscle tunic. On the sites the ganglia were found, the bundles of muscle fibers were pulled apart to make room for the myenteric neuronal groups (Fig 1).

The ganglia of the myenteric plexus assumed different shapes and sizes. Stellate, elongated (Fig 2) ganglia were found.

2. Length of cellular body of the myenteric neurons: the averages of the major axis of the cellular body of the neurons of animals from groups $\mathrm{NN}(10.54 \mu \mathrm{m})$ and $\mathrm{DN}(10.34 \mu \mathrm{m})$ did not attain significant differences. When the averages from groups ND $(12.03 \mu \mathrm{m})$ and DD $(13.77 \mu \mathrm{m})$ were compared with the former values (groups $\mathrm{NN}$ and DN), it was verified that the latter were larger. These results showed a statistically significant difference when compared by student's $T$ test. 


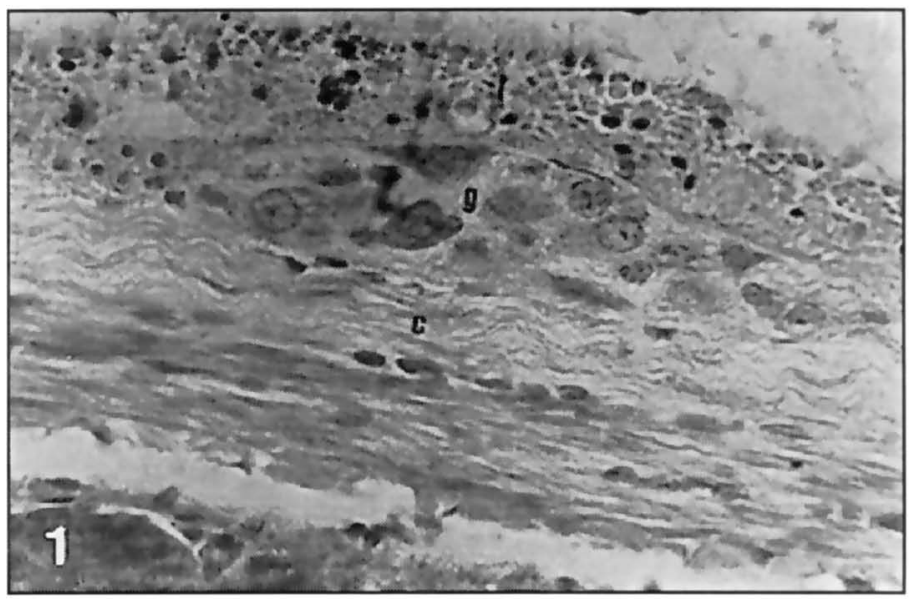

Fig $1.6 \mu$ m transverse section depicting a myenteric plexus ganglion (g), bundles of circular (c) and longitudinal (l) muscle fibers. Hematoxilin-Eosin. 433x.

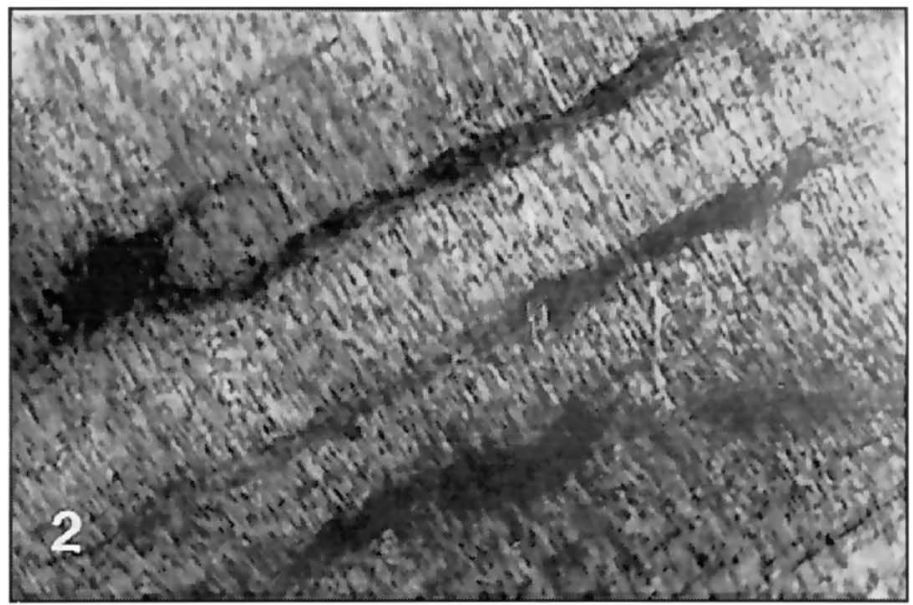

Fig 2. Whole mount preparations showing an elongated ganglion of the myenteric plexus. Giemsa. $108 x$.

3. Morphology of the myenteric neurons: on the various nutritional groups neurons with diverse sizes and shapes were found. Based upon morphological and staining features and length of the major axis of the cellular body, these neurons were distributed in two groups: a group of small neurons and another one of medium-sized and large neurons.

The small neurons had the major cellular body axis varying from 3.92 to $9.16 \mu \mathrm{m}$, the nucleus was often central and occupying most of the cellular body, and the nucleolus was usually absent. The reduced cytoplasm stained wearly. The medium-sized and large neurons had a cellular body with major axis ranging from 10.47 to $28.80 \mu \mathrm{m}$. Their large nucleus could appear in different positions within the cellular body: some were polar, on one of the extremes of the cell and involved by a little amount of cytoplasm on that extreme; others were peripheral, that is, displaced towards one of the cell's margins, with the cytoplasm equally distributed on the extremes. 1 to 2 well-defined nucleoli were observed, with a little tendency towards the two on the largest neurons. The cytoplasm filled most of the cellular body and stained strongly (Fig 3 and 4). 


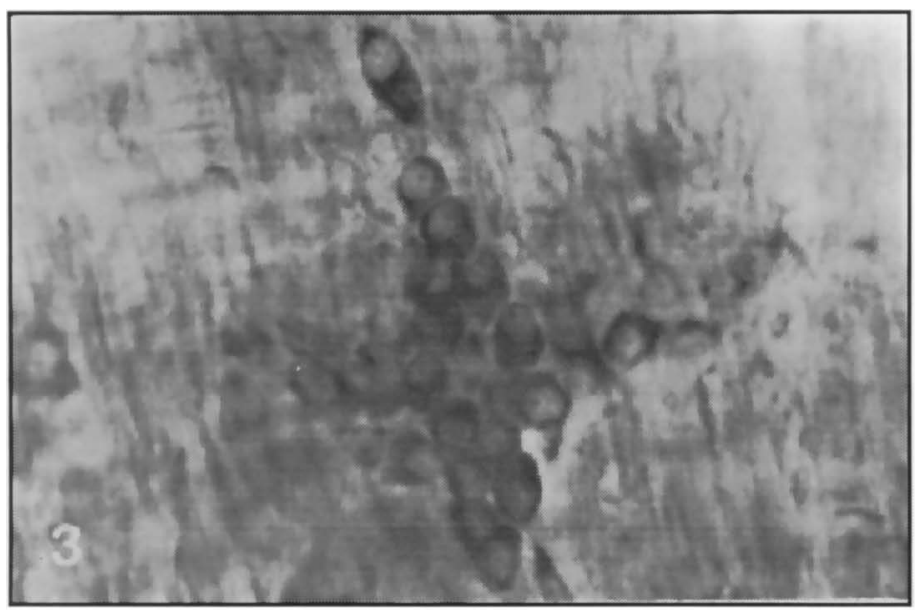

Fig 3. A stellate ganglion of the myenteric plexus, where large neurons are observed.Group DD. Giemsa. $433 x$.

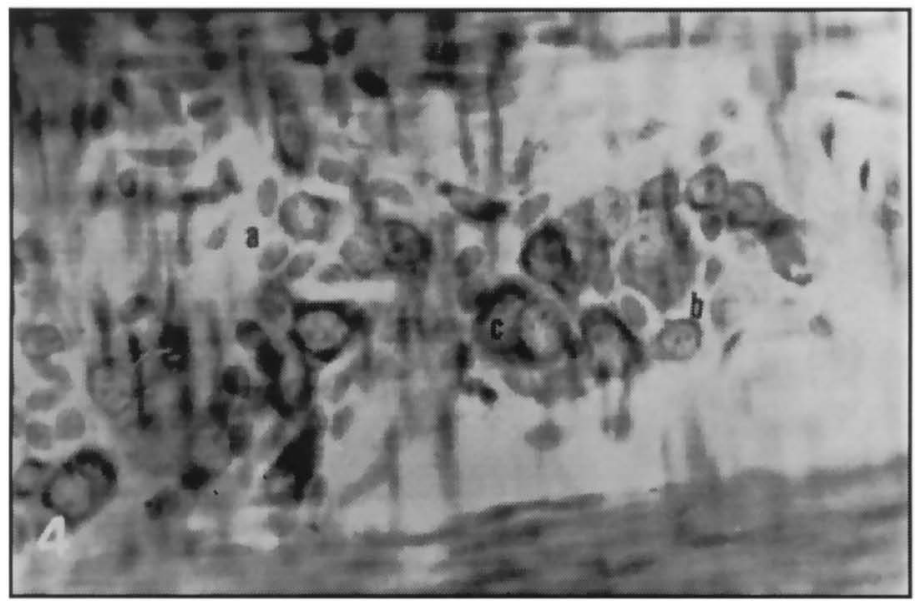

Fig. 4. A ganglion of the myenteric plexus, where small (a), medium-sized (b) and large (l) neurons are observed. Whole mount preparations stained with Giemsa. $433 x$.

4. Incidence of small and medium sized/large neurons: as describted previously, neurons considered small were those with the major axis of the cellular body ranging from $3.92 \mu \mathrm{m}$ to $9.16 \mu \mathrm{m}$, and neurons classified as medium-sized/large were those with dimensions from 10.47 up to $28.80 \mu \mathrm{m}$.

Table 1 presents the percentage of each group of small and medium sized/large myenteric neurons on the different nutritional groups. The analysis of these incidences revealed statistically significant differences when all groups were compared $\left(x^{2}=57.614\right)$. When groups were compared in pairs (NN and DN, NN and ND, ND and DN) the differences did not attain significance. However, when group DD was confronted with each of the others, the diferences did attain significance.

5. Density of neurons and ganglia per $\mathrm{cm}^{2}$ on the duodenum: Table 2 presents the average number of ganglia and neurons per $\mathrm{cm}^{2}$ on the duodenum in each nutritional group. Data concerning density of neurons when analysed by the $X^{2}$ method $\left(x^{2}=4652.48\right)$ showed differences statistically significant. The same result was reached on the analysis of the ganglionar density $\left(x^{2}=10.556\right)$. 
Table 1. Incidence of small, medium-sized and large myenteric neurons on the duodenum of animals belonging to the different mutritional groups.

\section{Groups}

$\begin{array}{lllll}\text { Variable } & \text { NN } & \text { DN } & \text { ND } & \text { DD } \\ \text { Small neurons }(<9.16 \mu \mathrm{m}) & 57 \% & 59 \% & 48 \% & 12 \% \\ \text { Medium-sized/Aarge neurons }(\geq 10.47 \mu \mathrm{m}) & 43 \% & 41 \% & 52 \% & 88 \%\end{array}$

$\mathrm{NN}$, normal nutrition during gestation and lactation; DN, undernutrition during gestation and normal nutrition during lactation; ND, normal nutrition during gestation and undernutrition during lactation; DD, undernutrition during gestation and lactation.

Table 2. Average values of the neuronal and ganglionar number per $\mathrm{cm}^{2}$ on the duodenum of rats belonging to the different nutritional groups.

\begin{tabular}{lllll}
\hline & \multicolumn{3}{c}{ Groups } \\
Variable Average & NN & DN & ND & DD \\
Number of neurons $/ \mathrm{cm}^{2}$ in the duodenum & 31438 & 31698 & 47598.6 & 38761.6 \\
Number of ganglia $/ \mathrm{cm}^{2}$ in the duodenum & 1109.2 & 1026 & 1145 & 1169 \\
\hline
\end{tabular}

$\mathrm{NN}$, normal nutrition during gestation and lactation; DN, undernutrition during gestation and normal nutrition during lactation; ND, normal nutrition during gestation and undernutriton during lactation; DD, undernutrition during gestation and lactation.

\section{DISCUSSION}

1. Length of the cellular body of the myenteric neuron. The smaller values were found in groups NN $(10.54 \mu \mathrm{m})$ and DN $(10.34 \mu \mathrm{m})$ but no significant difference exist between them. Yet when values from groups NN and DN were compared with those from groups ND $(12.03 \mu \mathrm{m})$ and DD $(13.77 \mu \mathrm{m})$ the result attaimed a significant difference. These data are contrary to those suggested by the authors ${ }^{4}$ who, when studyng the neurons of the superior celiac mesenteric ganglion of rats whose mothers were underfed during gestation, reported that they "seem smaller". Nevertheless the animals studied by these authors had been sacrificed 24 hours after birth and therefore without a period of recover from the imposed nutritional condition.

Morever, statistically significant differences were also found concerning the incidence of small and medium-sized / large neurons on group DD and that on the others. On the former only $12 \%$ of the neurons had dimensions equal or inferior to $9,16 \mathrm{~mm}$ and $88 \%$ had values of the major cellular body axis equal or superior to $10.47 \mu \mathrm{m}$.

A similar fact was verified on the group of animals whose mothers had a low protein intake during lactation (group ND); in this group the average of the major axis of the cellular body is also superior to the values of group $\mathrm{NN}$ and DN, whose average are similar. This suggest that maternal undernutrition during gestation does not affect the myenteric plexus cells of the young. This is in accordance with the results obtained in histochemical studies ${ }^{20}$, which do not reveal differences on the enzimatic activity of myenteric neurons of rats whose mothers had been protein deprived during gestation. However, these data are contrary to the observations of a number of authors ${ }^{3,26,27}$, who observed decrease on the number and size of neurons of the central nervous system after pre- and/or post-birth undernutrition.

The imposed undemutrition on the different groups does not alter neuronal density on the duodenum, so the possibility of elimination of small neurons and maintenance of the large ones cannot be considered. Evidence points out to an adaptive mechanism through which small neurons hypertrophied, so as to be better enabled to cope with a possible proteic deprivation. 
2. Morphology of the myenteric neurons. In this study, neurons were classified in small and mediumsized/large groups based on the major axis of the cellular body and on morphological and dying features. On the literature distinct classifications were found, based on morphological and functional data. In this way, Dogiel (1899), apud Furness and Costa ${ }^{7}$ classified enteric neurons in types I, II and III; these types were further confirmed by other authors ${ }^{2,9,22}$.

The classification adopted here is similar to that used by Cook and Burnstock ${ }^{5}$ who classified the neurons of the mice myenteric plexus in small, medium-sized and large. We have decided, however, to consider medium-sized and large neurons as members of the same group.

Observations made in this study revealed great differences on the length of the major axis of the myenteric neurons, which varied from 3.92 to $28.80 \mu \mathrm{m}$. On the other hand, mice neurons ranging from 10 to $35 \mu \mathrm{m}$ were observed'.

Beside that, myenteric neurons had different dying features which may have a relation with the cellular body dimensions. On the neurons with major axis equal or superior to $10.47 \mu \mathrm{m}$ (mediumsized and large), the cytoplasm stained more intensely, while small neurons had a less dying affinity.

The more intense synthetic activity of a neuron, the larger is the amount of granular endoplasmic reticulum and free polyribosomes. These estructures have affinity for basic dyes ${ }^{12,14}$ and are responsible for the more enhanced color verified on the medium-sized/large myenteric neurons. Thus, it can be assumed thar this group has a more intense synthesis than the small one.

Concerning nucleus position, our findings are in accordance with those described for the autonomic neurons of the periferal nervous system ${ }^{12}$; we found that most of the myenteric neurons have polar and peripherical nuclei. This special feature must not be confounded with the nucleus excentric position on neurons during the chromatolysis phase $\mathrm{e}^{6,12,24}$.

3. Neuronal and ganglionar density per $\mathrm{cm}^{2}$ on the duodenum. We found on group $\mathrm{NN} 31438$ neurons $/ \mathrm{cm}^{2}$ on the duodenum, while it was found $64346 / \mathrm{cm}^{2}$ on the small intestine of newborn and $9400 / \mathrm{cm}^{2}$ on adults ${ }^{*}$. These differences are due to variations on the intestine size: once the total number of neurons is the same since birth, it is to be expected that their density decreases as the intestine enlarges.

The values found in this work are intermediate because the animals were sacrificed at the age of 60 days, thus before reaching adult age, while those studied by Gabella ${ }^{8}$ were sacrificed at the age of 180 days and the average values presented refer to the whole intestine, instead of only the duodenum.

The confrontation of the ganglionar and neuronal density per $\mathrm{cm}^{2}$ on the 4 groups revealed statistically significant differences, yet we believe that these have little or no pathophysiological influence, for, contrary to the expected, the largest neuronal density was found on the groups more affected by the proteic deprivation; in this way groups ND and DD showed 47598.6 and 38761.6 neurons $/ \mathrm{cm}^{2}$ respectively, while groups $\mathrm{NN}$ and DN showed 31438 and 31698 neurons $/ \mathrm{cm}^{2}$.

Although the difference concerning intestinal length have not attained significance in relation to the significance level adopted, we verified on the groups ND and DD a shorter intestinal length than in on the groups $\mathrm{NN}$ and $\mathrm{DN}$; this fact could contribute to the greater neuronal density on groups ND and DD, considering that as the intestine grows the neurons disperse, thus reducing their number per $\mathrm{cm}$.

Our results are contrary to those of Santer and Conboy ${ }^{19}$, once these authors have found a $27 \%$ decrease on the number of neurons in rats with desnutrition during the first two weeks of gestation. It must be considered however that they sacrificed the animals at the $140^{\text {th }}$ day of age, while we did it at the $60^{\text {th }}$, aging leads to the reduction of the myenteric neurons $s^{8,16,18}$.

\section{CONCLUSIONS}

Based on our results we reached the following conclusions:

1. The myenteric ganglia of the duodenum of the rats may have an elongated, stellate shape.

2. The myenteric neurons cluster in ganglia despite the nutritional condition imposed to the group.

3. Based on the affinity for the Giemsa stain we can assert: there is a relationship between the length 
of the cellular body of the myenteric neurons and the basophilic cytoplasm; neurons with major cellular body axis equal or inferior to $9.16 \mu \mathrm{m}$ are less basophilic that those with axis equal or superior to $10.47 \mu \mathrm{m}$.

4. Animals submitted to undernutrition during gestation and lactation (DD) or just during lactation (ND) do not grow as much as animals of the same age but normally fed; as a consequence the myenteric neurons get less sparsed and yield a greater number per $\mathrm{cm}$.

5. In rats whose mothers were protein-deprived during gestation and lactation (DD), there is a greater incidence of medium-sized/large neurons and smaller incidence of small ones than on the other groups. This suggests that on the animals who suffered undernutrition during gestacion and lactation (group DD) developed an adaptive mechanism which caused storage of nutrients on the neurons, thus increasing the cellular body. This event would have taken place from the $21^{\text {st }}$ to the $60^{\text {th }}$ day of age, when the animals got a normal diet.

\section{REFERENCES}

1. Barbosa AJA. Técnica histológica para gânglios nervosos intramurais em preparados espessos. Rev Bras Pesq Méd e Biol 1978;11:95-97.

2. Brookes, $\mathrm{SJH}$, Costa $\mathrm{M}$. Identification of enteric motor neurones which innervate the circular muscle of the guinea-pig small intestine. Neuroscience Letters 1990;118:227-230.

3. Chase HP, Dabiere CS, Welch NN, O'Brien D. Intra uterine undernutrition and brain development. Pediatrics 1971;47:491-500.

4. ConboyVB, Santer RM, Swift GL. Effects of prenatal undemutrition on prevertebral sympathetic neurons in the rats: a morphorlogical and fluorescence histochemical study. J Anat, 1987;154: 47-53.

5. Cook DR, Burnstock G. The ultraestructure of Auerbach's plexus in the guinea-pig. 1. Neuronal elements. J Neurocytol,1976;5:171-194.

6. Erhart EA. Neuroanatomia. Ed 4.São Paulo; Atheneu 1974:3.

7. Fumess JB, Costa M. The enteric nervous system Edinburg: Churchill Livingstone, 1987:27-33.

8. Gabella $G$. Neuron size and number in the myenteric plexus of the newborn and adult rat. J Anat,1971;109:81-95.

9. Gabella G. Inervation of the gastrointestinal tract. Internat Rev Cytol 1979;59:129-193.

10. Gabella G.The number of neurons in the small intestine of mice, guinea-pig and sheep. Neuroscience 1987;22:737-752.

11. Gabella G. Fall in the number of myenteric neurons in aging guinea-pigs.Gastroenterology 1989;96:1487-1493.

12. Ham AW, Cormack DH. Histologia. Ed 9. Rio de Janeiro: Guanabara Koogan, 1993:273-286.

13. Irwim DA. The anatomy of Auerbach's plexus. Am J Anat 1931;49:141-166.

14. Junqueira LCU, Cameiro J. Histologia básica Ed 7, Rio de Janeiro: Guanabara Koogan, 1990:120-125.

15. Lepri ER. Desenvolvimento do córtex cerebelar de ratos na desnutrição protéica pré e pós natal. Dissertação de Mestrado, Universidade Federal do Paraná. Curitiba, 1988.

16. Moratelli HB. Estudo morfológico e quantitativo do plexo mientérico do intestino delgado humano em adultos jovens e idosos. Tese de Doutorado, Instituto de Ciências Biomédicas da Universidade de São Paulo. São Paulo, 1990.

17. Moura AS. Estudo em ratos do processo da adaptação à dietas com níveis variáveis de proteína com e sem restrição energética. Tese de Doutorado, Instituto de Ciências Biomédicas da Universidade da São Paulo. São Paulo,1984.

18. Santer RM, Baker DM. Enteric neuron numbers and sizes in Auerbach's plexus in the small and large intestine of adult and aged rats. Autonomic Nerv 1990; 25:59-57.

19. Santer RM, Conboy YB. Prenatal undernutrition permanently decreases enteric neuron and sympathetic innervation of Auerbach's plexus in the rat. J Anat, 1990;168:57-62.

20. Slirader RE, Zeman FJ. Effect of maternal protein deprivation on morphological and enzimatic development of neonatal rat tissue. J Nutrition 1969; 99:401-421.

21. Silva DJ. Análise de alimentos (métodos quimicos e biológicos). Viçosa: Imprensa Universitária da Universidade Federal de Viçosa, MG, 1981:33-46.

22. Stemini C. Structural and chemical organization of the myenteric plexus. Ann Rev Physiol 1988;50:81-93.

23. Tafuri WL, Campos FA. Auerbach plexus bei der Maus. Z Naturforsch 1958;13b:816-818.

24. Weiss L, Greep RO. Histologia. Ed 4. Rio de Janeiro: Guanabara Koogan, 1981:556-557.

25. Winick M. Nutrition and nerve cell growtl. Fed Proc Fed Am Socs Exp Biol 1970;29:1510-1515.

26. Winick M, Noble A. Cellular response in rats during malnutrition at various ages. J Nutrition 1966;89:300-306.

27. Winick $M$, Rosso $P$. The effect of severe early malnutrition on cellular growth of human brain. Pediatrics Res $1969 ; 3: 181-184$. 